\title{
Bone Weathering in a Periglacial Environment: The Tayara Site (KbFk-7), Qikirtaq Island, Nunavik (Canada)
}

\author{
DOMINIQUE TODISCO ${ }^{1}$ and HERVÉ MONCHOT ${ }^{2}$
}

\author{
(Received 15 February 2007; accepted in revised form 20 July 2007)
}

\begin{abstract}
Bone weathering analysis of the Palaeoeskimo Tayara site (Qikirtaq Island, Nunavik, Canada) documents site taphonomy in the Arctic periglacial environment. Like a majority of sites in the eastern Canadian Arctic, Tayara has a faunal assemblage dominated by marine mammals (seal, walrus, and beluga whale) and some terrestrial mammals (caribou, fox, and bear). Statistical and spatial analyses of five weathering stages reveal that large mammal bone preservation is generally good and does not seem to be influenced by taxonomic and skeletal differences. The good preservation of the faunal assemblage seems to have been favored by the burial of bones and their incorporation into the active layer, which suggests only limited mechanical deterioration (i.e., freeze-thaw or wet-dry cycles, or both) before or at the time of burial. Burial depth partly explains the degree of bone weathering. Indeed, the well-preserved bones are found mainly where burial is associated with thicker overlying sediments. This implies rapid bone burial with a low degree of exposure to temperature changes and atmospheric processes. However, analysis also shows the presence of highly weathered bones where burial is associated with thicker overlying sediments. Consequently, differential bone depth probably does not explain all bone-weathering variability within the site. These results show the importance of examining bone weathering before any archaeozoological and paleoethnographic interpretations.
\end{abstract}

Key words: bone weathering, taphonomy, large mammals, periglacial environment, spatial analysis, Palaeoeskimo

RÉSUMÉ. L'analyse méthodique de la météorisation osseuse des restes fauniques du site paléoesquimau de Tayara (île Qikirtaq, Nunavik, Canada) documente la taphonomie d'un site archéologique en contexte périglaciaire arctique. Comme dans la plupart des sites arctiques de l'Est canadien, l'assemblage faunique de Tayara est dominé par des mammifères marins (phoque, morse et béluga) plus quelques mammifères terrestres (caribou, renard et ours). Les analyses statistiques et spatiales selon cinq stades d'altération reconnus montrent une bonne conservation des restes osseux des grands vertébrés, qui ne semble pas être influencée par les différences taxonomiques et squelettiques. La bonne conservation de l'assemblage osseux semble avoir été favorisée par l'enfouissement des ossements et leur incorporation dans la couche active. Ceci suggère une détérioration mécanique pré- et synenfouissement limitée (i.e., cycles gel-dégel et/ou d'hydratation-dessiccation). La profondeur d'enfouissement explique en partie le degré de préservation des ossements. En effet, les ossements les mieux conservés se rencontrent principalement dans les zones où les sédiments de recouvrement sont les plus épais. Ceci implique un enfouissement rapide ainsi qu' un faible degré d'exposition des ossements aux changements de température et aux processus atmosphériques. Les analyses montrent aussi la présence de quelques os fortement détériorés situés dans les zones où les sédiments sont les plus épais. De ce fait, la profondeur différentielle des ossements n'explique probablement pas toute la variabilité de la conservation osseuse dans le site. Ces résultats illustrent ainsi l'importance d'une étude taphonomique préalable sur la conservation d'un assemblage faunique avant toute interprétation archéozoologique et palethnographique.

Mots clés : météorisation osseuse, taphonomie, grands mammifères, environnement périglaciaire, analyse spatiale, paléoesquimau

Traduit pour la revue Arctic par Nicole Giguère.

\section{INTRODUCTION}

Originally defined by Efremov (1940) as the laws of embedding or burial, taphonomy is the study of the physical, biological, and cultural processes that result in the post-mortem modifications of animal remains such as bones. Explicit interest in archaeological site formation processes has brought the concept of taphonomy to the attention of archaeologists (Schiffer, 1983). Several taphonomic studies dealing with different periods and geological contexts (Denys et al., 1997) have been carried out in different kinds of environments, such as temperate regions (Andrews and Cook, 1985; Andrews and ArmourChelu, 1997), tropics (Behrensmeyer, 1978; Tappen, 1994), and northern latitudes (Sutcliffe, 1990). Nevertheless, archaeological studies in active periglacial environments

\footnotetext{
${ }^{1}$ Département de Géographie et Centre d'études nordiques, Pavillon Abitibi-Price, Université Laval, Québec, Québec G1K 7P4, Canada; domitodi@yahoo.fr

${ }^{2}$ Département de Préhistoire, UMR 5198, Muséum national d'Histoire naturelle, Institut de Paléontologie Humaine, 1, rue René Panhard, 75013, Paris, France; herve.monchot@wanadoo.fr

(C) The Arctic Institute of North America
} 
of northern regions have often neglected taphonomy. This is especially true for the study of bone preservation in the active layer of permafrost-affected soils. Moreover, to date there have been no studies that have dealt with intrasite bone weathering analyses according to taxa, anatomical differences, and bone depth and location within the site. The study of bone weathering is essential because it provides information on the processes that determine bone preservation or deterioration before, during, and after burial (Behrensmeyer, 1978; White and Hannus, 1983; Lyman and Fox, 1989; Lyman, 1994; Denys et al., 1997). Understanding taphonomic processes is an important prerequisite for paleoethnographic and zooarchaeological interpretations. In order to better understand bone preservation in a periglacial environment, we document the bone taphonomy of the Palaeoeskimo Tayara site through statistical and spatial analyses of bone weathering.

\section{STUDY SITE}

The open-air Tayara site (KbFk-7) is located on Qikirtaq Island at the mouth of Sugluk Fjord, about $10 \mathrm{~km}$ northeast of Salluit $\left(62^{\circ} 14^{\prime} \mathrm{N} ; 75^{\circ} 38^{\prime} \mathrm{W}\right)$ on the southern shore of Hudson Strait (Nunavik, Canada) (Fig. 1). The Salluit region was scoured by the Laurentide ice sheet, and Sugluk Fjord was deglaciated circa 8000-7500 yr BP (Gray et al., 1993; Kasper and Allard, 2001). The area is in the continuous permafrost zone and is characterized by an active periglacial morphoclimatic system (Allard and Séguin, 1987; Kasper and Allard, 2001). The present-day regional climate is semiarid Arctic, with polar temperatures and a very short growing season (Gérardin and McKenney, 2001). Climatic data from the Salluit weather stations indicate a mean annual temperature of about -7 to $-8^{\circ} \mathrm{C}$ (Bouchard, 2005). Mean annual precipitation is about $310 \mathrm{~mm}$, with approximately $53 \%$ falling as snow (Kasper and Allard, 2001). The area is in the bioclimatic domain of Arctic herbaceous tundra.

Tayara is a key Palaeoeskimo site for understanding the Initial Dorset phase in the Arctic (Desrosiers and Gendron, 2004; Desrosiers et al., 2006). It was first studied by Taylor (1968), who defined the continuity between PreDorset and Early Dorset phases. Most of Taylor's archaeological material comes from the central area of the site, corresponding to trenches 1, 2, and 3 (Fig. 2). New excavations concentrated on this area, which occupies a raised sandy beach $175 \mathrm{~m}$ from the current shore at $18 \mathrm{~m}$ a.s.l. These excavations made it possible to link almost all of Taylor's trenches together, permitting greater stratigraphic control and better understanding of the site's occupation and formation processes (Avataq Cultural Institute, 2004; Todisco and Bhiry, in press). The site is characterized by three main superimposed Palaeoeskimo archaeological levels (Desrosiers and Gendron, 2004). The most recent one (level I) and its base in Taylor's trench 1 extension (level IA) (Fig. 2) revealed no organic materials and only a few isolated Dorset artifacts. Level II (the best known

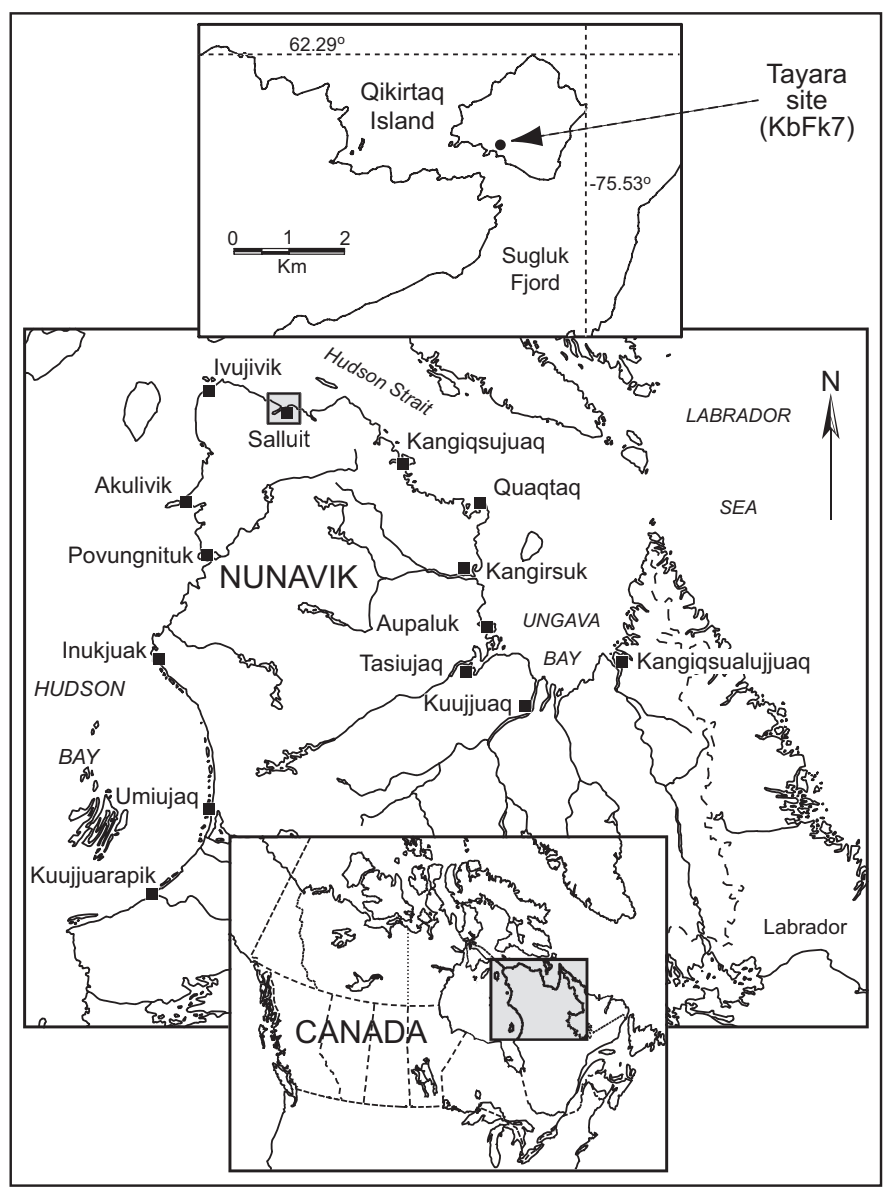

FIG. 1. Location of the study area.

level) is rich and revealed well-preserved organic materials, a significant number of faunal remains (Table 1), and many lithic artifacts. Most artifacts from this level are associated with the usual Middle Dorset tool-kit found in Nunavik (Avataq Cultural Institute, 2004; Desrosiers and Gendron, 2004). AMS radiocarbon dating from six charcoal fragments indicates a Middle Dorset age for level II of 1900 to 2100 uncalibrated yr BP (Gendron et al., 2003; Desrosiers and Gendron, 2004). Only a few square meters were opened in the older Palaeoeskimo level (level III), but very few diagnostic artifacts were retrieved. AMS radiocarbon dating from one charcoal fragment from this level indicates a Palaeoeskimo occupation at around 2500 uncalibrated yr BP (Gendron et al., 2003).

In Taylor's trench 2 and trench 3 extensions, deposits mainly consist of sand with interbedded or intermixed fines (silt-clay) (Fig. 2). They are likely stream-laid deposits, related to seasonal meltwater sedimentation associated with waxing and waning water discharge. Stream features include small-scale bars, and more related-channel deposits are locally represented by cross-stratified sands (not observed in the archaeological levels). In Taylor's trench 1 extension, stream-laid deposits are overlain by a soliflucted, matrix-supported diamicton that covers approximately one-third of the excavated surface (Todisco and Bhiry, in press). A solifluction sheet directly 


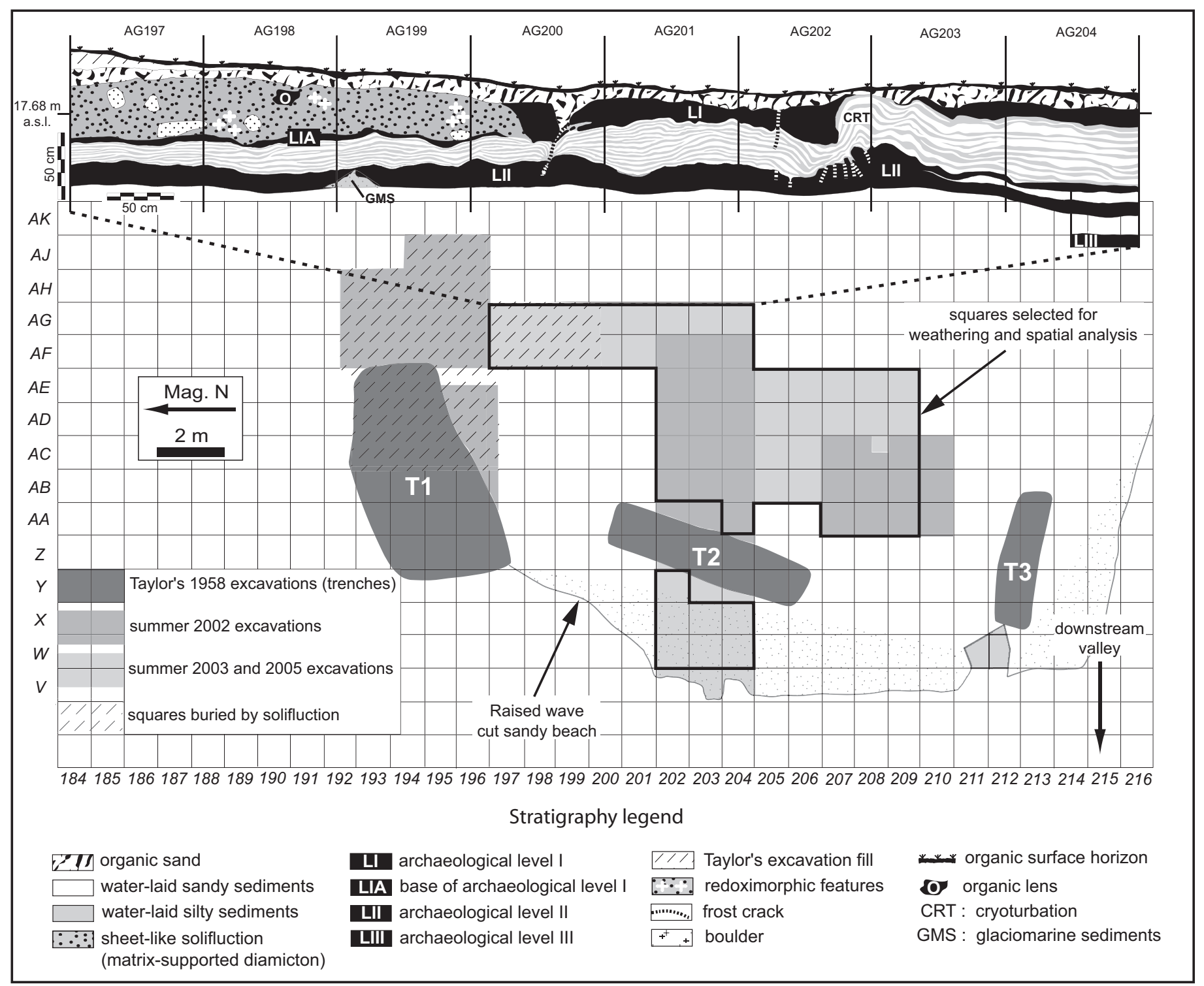

FIG. 2. Map of the Tayara site, showing Taylor's initial 1958 trenches and new excavations (modified from Avataq Cultural Institute, 2004). Squares selected for weathering and spatial analysis are indicated. Schematic stratigraphy is also shown from squares AG197 to AG204 east.

buried level IA without affecting levels II or III. Faunal and lithic remains are generally embedded in organic to organo-mineral horizons that are intermingled or interlayered with water-laid sediments. Archaeological levels and stream-laid deposits are locally affected by cryogenic processes such as cryoturbation and frost-cracks (Fig. 2). These processes generally occur in the active layer, i.e., the layer that thaws every summer over the permafrost table and refreezes in winter.

\section{METHODS}

\section{Bone Weathering Identification}

Weathering is defined by Behrensmeyer (1978:153) as "the process by which the original microscopic organic and inorganic components of bone are separated from each other and destroyed by physical and chemical agents operating on the bone in situ, either on the surface or within the soil zone." Consequently, each weathering stage (WS) represents a discrete segment of the continuous process of bone deterioration (Behrensmeyer, 1978; Darwent, 1995). According to direct observations of bones and descriptions based on easily observable criteria (i.e., macroscopic and mechanical rather than chemical criteria), we defined five mutually exclusive weathering stages (WS1 through WS5, increasing in the degree of weathering) in relation to the characteristics of the studied bones (Table 2). In addition to WS, evidence of root etching and mineralization were noted in a qualitative manner. To control potential taxonomic variations in bone weathering, the WS of each taxon was recorded separately. Bone weathering analysis was carried out by squares, mainly on 
TABLE 1. Faunal list of Tayara site for level II (85 squares) and level III (16 squares).

\begin{tabular}{|c|c|c|c|c|c|}
\hline & \multicolumn{2}{|c|}{$\mathrm{NISP}^{1}$} & \multirow[b]{2}{*}{$\%$ NISP total } & \multirow[b]{2}{*}{$\mathrm{MNI}^{2}$} & \multirow[b]{2}{*}{$\% \mathrm{MN}$} \\
\hline & Level II 85 squares & Level III 16 squares & & & \\
\hline \multicolumn{6}{|l|}{ Sea Mammals } \\
\hline Seals & 1518 & 72 & 44.9 & $\min .15$ & 30 \\
\hline Walrus (Odobenus rosmarus) & 216 & 9 & 6.4 & 8 & 16 \\
\hline Beluga whale (Delphinapterus leucas) & 21 & 0 & 0.6 & 2 & 4 \\
\hline 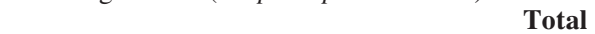 & 1755 & 81 & 51.9 & 25 & 50 \\
\hline \multicolumn{6}{|l|}{ Land Mammals } \\
\hline Caribou (Rangifer tarandus) & 148 & 2 & 4.2 & 4 & 8 \\
\hline Foxes (Alopex lagopus/Vulpes vulpes) & 367 & 1 & 10.4 & 17 & 34 \\
\hline Polar bear (Ursus maritimus) & 12 & 1 & 0.4 & 2 & 4 \\
\hline Wolf (Canis lupus) & 3 & 0 & 0.1 & 1 & 2 \\
\hline Human (Homo sapiens) & 2 & 0 & 0.1 & 1 & 2 \\
\hline Total & 532 & 4 & 15.2 & 25 & 50 \\
\hline \multicolumn{6}{|l|}{ Other Remains } \\
\hline Birds & 158 & 6 & 4.6 & - & - \\
\hline Rodents (e.g., lemmings) & 26 & 1 & 0.8 & - & - \\
\hline Total & 184 & 7 & 5.4 & - & - \\
\hline \multicolumn{6}{|l|}{ Unidentified Bones } \\
\hline Splinters & 362 & 8 & 10.4 & - & - \\
\hline Small size & 248 & 8 & 7.2 & - & - \\
\hline Medium size & 318 & 18 & 9.5 & - & - \\
\hline Large size & 14 & 0 & 0.4 & - & - \\
\hline Total & 942 & 34 & 27.5 & - & - \\
\hline TOTAL & 3413 & 126 & 100 & 50 & 100 \\
\hline Worked Bones and Ivory Fragments & 582 & 14 & - & - & - \\
\hline
\end{tabular}

${ }^{1}$ NISP $=$ Number of identified specimens.

${ }^{2} \mathrm{MNI}=$ Minimum numbers of individuals.

bones derived from level II, with additional observations on material from level III. Behrensmeyer (1978) has suggested that different skeletal elements will weather at different rates, perhaps because of variation in their structural density (Lyman and Fox, 1989). To control for this variable, we recorded the maximum WS displayed by different skeletal elements: skull, vertebrae, ribs, long bones (humerus, radius, ulna, femur, tibia, fibula), short bones (metapodials, phalanges) and compact bones (carpals, tarsals, sesamoids). Each bone identified to taxon or skeletal element, or both, was assigned a WS. Bones showing recent fractures (made during digging) and bones recovered from sieving (essentially micro-splinters, antler fragments, isolated teeth, costal cartilage, and some small unidentified fragments) were not assigned a WS.

\section{Statistical Tests for Randomness of Distribution and Spatial Association}

Variance to Mean Ratio (VTMR) and contingencytable statistical tests were applied to test the dispersion and the association of bones. Both tests examine randomness and association between parameters (Dacey, 1973; Pielou, 1977; Monchot et al., in press). The VTMR is a simple Poisson test that offers a means of measuring the aggregation and intensity of a pattern. The null hypothesis $H_{0}$ signifies a random pattern. Contingency-table tests were used to address the issue of aggregation strength (spatial association) between pairs of parameters (Dacey, 1973; Pielou, 1977). The significance of the VTMR test and contingency table were calculated using chi-square statistics $\left(\chi^{2}\right)$. In addition, we used the Kolmogorov-Smirnov (ZKS) test with D statistics to test for significance of association between selected parameters (Klein and CruzUribe, 1984). These univariate tests are well suited to the Tayara site because they are based on partitioning a map region into "n non-overlapping subregions of constant size and shape" (Dacey, 1973:321). At Tayara, these subregions correspond to excavation units one meter square, a total of 59 completely excavated squares for level II. These 59 squares (Fig. 2), which represent approximately $70 \%$ of the $851 \mathrm{~m} \times 1 \mathrm{~m}$ squares opened between 2002 and 2005, were examined for randomness. The spatial association of the WS of the faunal remains recovered (including subcategories of faunal species and skeletal elements) was also examined.

\section{Spatial Autocorrelation Statistics}

To control for weathering similarity between squares and for preferential areas of bone preservation, three categories of weathering were created and mapped. The WS were regrouped as follows: WS1+2 (good bone preservation), WS3 (medium bone preservation) and WS4+5 (poor bone preservation). We then calculated the percentage of each square corresponding to each category (WS\%). Spatial autocorrelation statistics (Cliff and Ord, 1973; Goodchild, 1986) were used to test the null hypothesis $H_{0}$ of no spatial autocorrelation between WS\% per square throughout the site. Square data were imported into MapInfo 
TABLE 2. Definition of weathering stages (WS) for the bone assemblage of the Tayara site (modified from Behrensmeyer, 1978).

\begin{tabular}{|c|c|}
\hline WS & Definition of weathering stage \\
\hline 1 & Fresh bone aspect with no cracking or flaking. Smooth surface without cracks/fissures. Unweathered stage. \\
\hline 2 & $\begin{array}{l}\text { Cracking parallel to fiber structure (longitudinal) in long bones. Incipient cracks in flat, short and irregular bones. Exfoliation started. } \\
\text { Very limited surface weathering with a slight crazed appearance. }\end{array}$ \\
\hline 3 & $\begin{array}{l}\text { Flaking of outer surface usually associated with cracks. Flakes are long and thin with one edge attached to bone. Longer and wider } \\
\text { fissures. Advanced exfoliation. }\end{array}$ \\
\hline 4 & $\begin{array}{l}\text { Bone surface coarse, rough, and fibrous. Large and small splinters loosely attached. Weathering penetrates to inner cavities. Cracks } \\
\text { largely open. Spongy bone visible. }\end{array}$ \\
\hline 5 & $\begin{array}{l}\text { Bone mechanically failing into pieces, very fragile, dusty. Bones generally unidentified, without cortical layer (only trabeculated, } \\
\text { spongy bone). Bones severely deteriorated. }\end{array}$ \\
\hline
\end{tabular}

Professional version 6.5 GIS software, and topologic links for each WS\% category were generated using Queen's contiguity up to the seventh-order lag. The index of global spatial autocorrelation (GSA), i.e., the I of Moran, was calculated using the MapStat package (version 1.2) (Thériault, 1998). Results of univariate global Moran's I are presented under both the normality and randomization assumptions with one-tailed significance tests. Moran's spatial correlograms were constructed using global Moran's I to estimate the strength of the spatial correlation between WS\% per square as a function of the seven orders of contiguity.

To test the null hypothesis $H_{0}$ of no association between the WS1+2\% observed within squares and values observed in neighboring squares, data were imported into GeoDa 0.9.5-i software (Anselin, 2003). Local spatial autocorrelation analysis was based on the Local Moran LISA statistics (Anselin, 1995). Univariate local Moran's $\mathrm{I}(\mathrm{LI})$ for $\mathrm{WS} 1+2 \%$ per square was computed to determine local indicators of spatial association (LISA). LI was computed for a raw-standardized spatial weights matrix based on first-order Queen's contiguity. LISA maps were drawn (after carrying out 9999 permutations) to assess the hypothesis of spatial randomness of weathering and to identify local hot or cold spots of well-preserved bones that were statistically significant in comparison to spatial randomness. In addition, we drew the univariate Moran's scatterplot for WS $1+2 \%$ per square in order to visualize local instability in GSA and types of local spatial association (Anselin, 1995).

\section{RESULTS}

\section{Faunal Remains}

A total of 3539 bones for the whole excavation were recovered: none in level I, 3413 in level II, and 126 in level III. Of all the bones analyzed, $78 \%$ were identified to species (Table 1). The majority of the identified bones belong to sea mammals. Among these, seal bones are the most abundant, comprising $44 \%$ of the assemblage. Two species are represented, clearly differentiated by size and morphology: the bearded seal (Erignathus barbatus) and the ringed seal (Phoca hispida). Because the identification of seal species is difficult and incomplete, many bones cannot be identified to species, especially those belonging to juveniles. In addition, we cannot exclude the presence of harbor seal (Phoca vitulina) and harp seal (Phoca groenlandica), both migratory species. Another sea mammal hunted by the Palaeoeskimos of Tayara was walrus (Odobenus rosmarus), represented at this site by at least eight individuals. Cetaceans are represented by beluga whale (Delphinapterus leucas) remains, and the remains of terrestrial mammals include fox (Alopex lagopus/Vulpes vulpes), polar bear (Ursus maritimus), caribou (Rangifer tarandus) and wolf (Canis lupus). No fish or hare remains were recorded. The 164 bones that were identified as belonging to birds may be attributed to geese, eider ducks, ptarmigan, gulls, and loons. In addition, we confirmed the presence of 596 worked organic tools, primarily consisting of needles, punches, and harpoons made from bone, ivory or antler. To control for potential taxonomic variation in bone weathering, we chose four categories for examination: 1) large sea mammals (belugas and walruses), 2) small sea mammals (seals), 3) terrestrial mammals (essentially caribou and polar bears), and 4) unidentified bones (splinters). Worked bones, ivory fragments, and fox and bird bones were excluded from the analysis.

\section{Taphonomy and Human Modifications}

Over $50 \%$ of the bones from the excavated assemblage are complete or partially complete. For seal and walrus remains, all skeletal elements are present, which suggests that these animals were entirely transported to the site by Palaeoeskimos rather than scavenged from beached carcasses. The pattern of destruction is similar for both species. Walrus skull elements were found in relatively high proportion because Palaeoeskimos used their ivory for making tools (LeMoine and Darwent, 1998). Caudal vertebrae, carpals, tarsals, metapodials, phalanges, and long bones are typically complete or partially complete because of their compact nature, while spongier bones such as vertebrae or ribs are highly fragmented. The high fragmentation of ribs and vertebrae in all age categories may correlate to the fact that the rib cage contains most of the meat and blubber (especially in seals) (Lyman, 1992; Lyman et al., 1992). Thus, these elements may have been 
crushed during the butchering process. It is highly unlikely that bone grease was rendered through the boiling of crushed ribs and vertebrae, since they appear to contain very little grease (at least among small seals). In the case of axial elements, trampling might have been another important factor in their fragmentation (Darwent, 1995). However, for other bones, their limited polish and edgerounding suggest minimal trampling.

For caribou, limb extremities are over-represented $(48.4 \%)$, which may reflect the preferential selection of bones such as metapodials for tool material. This high frequency may be related to the high density of these bones, or to transport factors, i.e., the fact that metapodials are attached to elements of high meat utility (Lyman, 1984, 1994). Tool manufacture is suggested by the fact that metapodials are mainly represented by longitudinal shaft fragments, with very few distal extremities. Spiral fractures and marks of longitudinal groove-splitting would be remnants of tool manufacture since they are associated with the breaking of fresh bones. The butchering technique used by the site's inhabitants did not involve much cutting into bones: only 10 bones clearly show cut marks. This result contrasts with the $11.9 \%$ cut marks on bones of harbor seals from sites on the Oregon coast (Lyman, 1992), but it is very similar to the percentage of cut marks observed for Palaeoeskimo sites from the Ivujivik area, Nunavik (Nagy, 1997). The minimal human-induced fragmentation of the Tayara bone assemblage indicates that most bone modifications can be reasonably attributed to non-cultural agents.

\section{Taphonomy and the Burial Process}

All analyzed bones were buried and concentrated in the active layer at varying depths. Burial in a low-energy sedimentary environment with limited postdepositional reworking and damage of archaeological remains is suggested by 1) the lack of water-rolled bones and abrasion features associated with water erosion (Hill, 1979; Haglund, 1991; Littleton, 2000); 2) the fact that all skeletal elements are represented (limited bone sorting); 3 ) the presence of small and light elements, such as fox and bird bones; 4) the abundance of lithic flakes (Avataq Cultural Institute, 2004), most of which are very small, light and fragile; 5) the absence of significant sorting of lithic artifacts, which likely indicates a limited subtractive effect by gently flowing water (Todisco and Bhiry, unpubl. data), and 6) the structure and organization of the site, which revealed many clusters of bones (butchering areas) and lithic artifacts (knapping/debitage areas). A significant postdepositional spatial rearrangement of the remains seems to be unlikely. However, because some bones show a preferred orientation (Todisco and Bhiry, unpubl. data), a slight bone reorientation caused by gently flowing water could not be excluded in some squares (Todd and Frison, 1986; Behrensmeyer, 1990; Lyman, 1994). The presence of many seal skeletal units such as extremities (for instance, flipper bones comprising 31 connected metapodials, phalanges and sesamoids were found in square AG203) and trunk vertebrae are good indications of 1) minimal transport and bone dispersal by Palaeoeskimos during and after animal butchering (i.e., the remains were likely near the original butchering location) and 2) rapid burial. The presence of mandibles with teeth still in their alveoli (for seal, walrus, beluga, fox, wolf, and caribou) and the presence of fetal/newborn seal remains (including vertebrae, radius, humerus, ulna, tibia, metapodial, and phalanges, all of which are very small, light and fragile) also indicate that bones are well preserved and that there was very little post-mortem deterioration.

\section{Weathering Analyses}

In total, 1667 bone remains were recovered from the 59 selected squares and studied in regard to weathering; 1605 belong to level II and 62 to level III, which was excavated in only seven squares. Among the analyzed bones, 1082 $(1033+49)$ belong to seals, $162(154+8)$ to large sea mammals, $144(141+3)$ to terrestrial mammals, and 279 $(277+2)$ are unidentified. All analyzed bones were not bleached and were characterized by an absence of soft tissues, greasy appearance, and macroscopic lichens or algae at their surface. Their excellent preservation (Figs. 3 and 4) is confirmed by the fact that for level II, 895 bones belong to WS1 (56.5\%), 431 to WS2 (27.2\%), 161 to WS3 $(10.1 \%), 83$ to WS4 (5.2\%) and 15 to WS5 (1\%). For level III, 42 bones belong to WS1 (67.7\%), 19 to WS2 (30.7\%), and only one bone to WS3 (1.6\%). For level II, the test for randomness clearly indicates a non-random distribution of the bones (all taxa and skeletal elements considered) through the different WS (Table 3). When spatial associations between all possible pairs of WS are tested (all taxa and skeletal elements considered), a correlation is found between continuous WS (Table 4). This emphasizes the fact that WS are not discrete natural categories and that weathering is a continuous process.

Polar bear remains $\left(\chi^{2}=59.95 ; \mathrm{df}=58 ; p=0.405\right)$ and wolf remains $\left(\chi^{2}=56.96 ; \mathrm{df}=58 ; p=0.514\right)$ are randomly distributed and were excluded from further analyses because of their small sample sizes. Other species are nonrandomly distributed according to the VTMR: seals $\left(\chi^{2}=\right.$ $716.434 ; \mathrm{df}=58 ; p<0.001)$, walrus $\left(\chi^{2}=109.126 ; \mathrm{df}=58\right.$; $p<0.001)$, beluga $\left(\chi^{2}=97.945 ; \mathrm{df}=58 ; p<0.001\right)$, and caribou $\left(\chi^{2}=259.506 ; \mathrm{df}=58 ; p<0.001\right)$. The $\chi^{2}$ for walrus/beluga shows a significant association $\left(\chi^{2}=4.035\right.$; $\mathrm{df}=1 ; p=0.044)$ as does that for walrus/seal $\left(\chi^{2}=9.570\right.$; $\mathrm{df}=1 ; p=0.002)$. The $\chi^{2}$ test is not significant at the 0.05 level for the other paired associations such as beluga/ caribou $\left(\chi^{2}=1.658 ; \mathrm{df}=1 ; p=0.1978\right)$, beluga/seals $\left(\chi^{2}=0.640 ; \mathrm{df}=1 ; p=0.4237\right)$, walrus $/$ caribou $\left(\chi^{2}=3.725\right.$; $\mathrm{df}=1 ; p=0.0536)$ and seals/caribou $\left(\chi^{2}=3.696 ; \mathrm{df}=1\right.$; $p=0.0545)$. These results indicate that a correlation exits in the spatial distribution of some species (walrus/beluga and walrus/seal). On the other hand, there are also some 


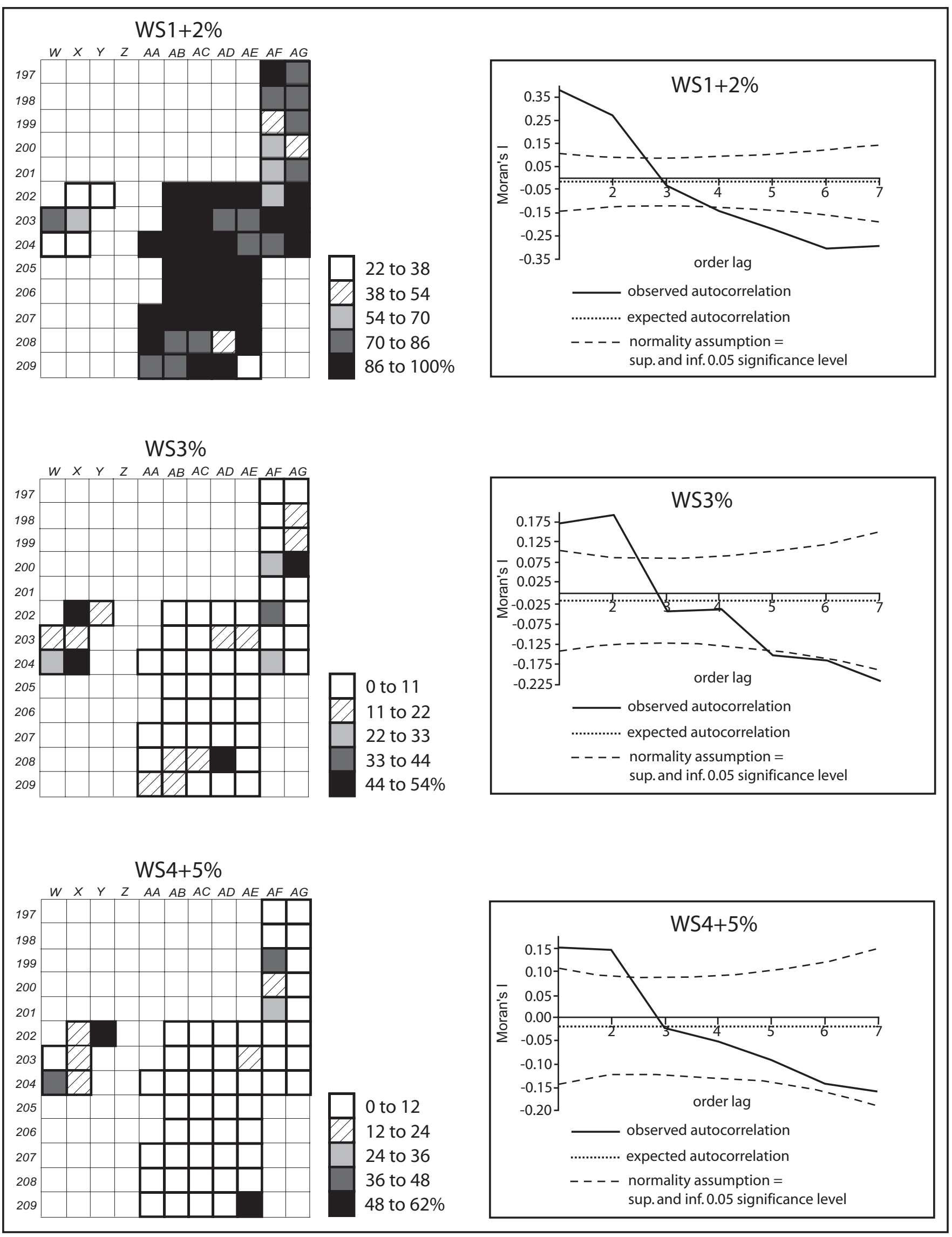

FIG. 3. Density maps (in percentage of bones) for the three weathering categories of level II and corresponding Moran's I spatial correlograms. The excavated square W202 was not mapped because it lacked identified bone remains. 


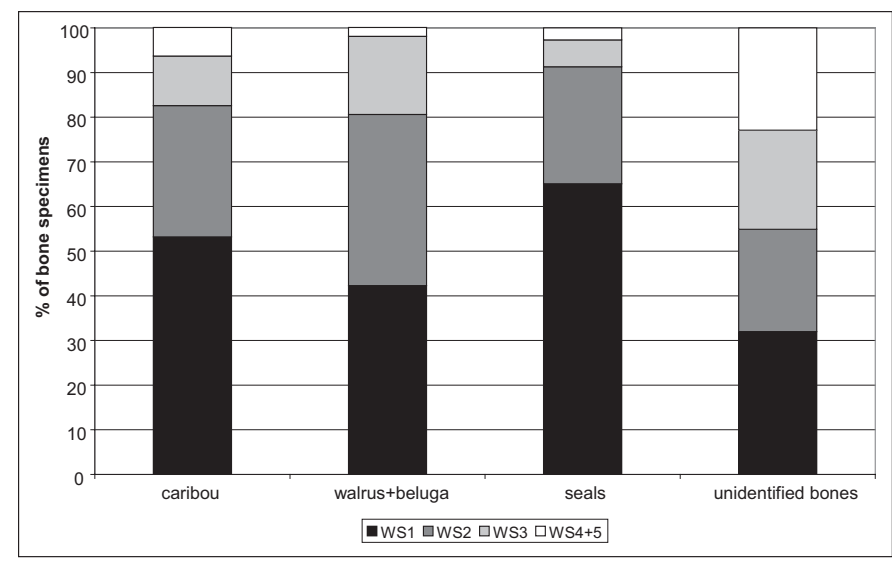

FIG. 4. Weathering profiles for caribou, walrus, beluga, seals, and unidentified bones of level II (all skeletal elements considered). Kolmogorov Smirnov Z with D statistics between all possible pairs of species for the different WS (WS1, WS2; WS3; WS4+5): ZKS caribou/seals $=0.906, \mathrm{D}=0.087, p<0.05$ (NS = no significant); ZKS caribou/walrus-beluga $=0.382 ; \mathrm{D}=0.046 ; p<0.05$ (NS); ZKS seals/walrus-beluga $=1.198, \mathrm{D}=0.104, p<0.05$ (NS).

independent distributions (caribou). These differences in species distribution could be explained by the fact that Tayara represents multiple events of hunting, and that Palaeoeskimos did not butcher all animals in the same place at the same time. This suggests selective butchering areas on the site especially for sea mammals or caribou.

In spite of some differences in weathering stage profiles for the different skeletal parts of the species (Table 5), the distribution of WS between belugas and walruses (WS1+2 $=80.5 \% ; \mathrm{WS} 3=17.5 \%$; WS $4+5=2 \%)$, seals $(\mathrm{WS} 1+2=$ $91.3 \%$, WS3 $=6 \%$; WS $4+5=2.7 \%$ ), and caribou (WS $1+2$ $=82.5 \%$; WS $3=11.1 \%$; WS $4+5=6.4 \%$ ) appears to be similar, as shown by the ZKS test (Fig. 4). Analysis shows that WS are not correlated with specific species (all body
TABLE 3. Test for randomness of distribution for the five different weathering stages (WS) of level II (all taxa and skeletal elements considered).

\begin{tabular}{lccccc}
\hline \hline & WS1 & WS2 & WS3 & WS4 & WS5 \\
\hline Mean (m) & 15.169 & 7.305 & 2.729 & 1.407 & 0.254 \\
Variance (v) & 235.867 & 30.423 & 9.477 & 5.590 & 1.158 \\
Ratio (v/m) & 15.549 & 4.164 & 2.67 & 3.972 & 4.559 \\
Number of cells (n) & 59 & 59 & 59 & 59 & 59 \\
$\chi^{2}$ (nv/m) & 917.391 & 245.716 & 204.889 & 243.406 & 268.984 \\
$p$-value (df = 58) & $<0.001$ & $<0.001$ & $<0.001$ & $<0.001$ & $<0.001$ \\
Distribution & $\mathrm{NR}^{1}$ & NR & NR & NR & NR \\
\hline \hline
\end{tabular}

${ }^{1} \mathrm{NR}=$ non-random distribution.

TABLE 4. Chi-square statistics between all possible pairs of weathering stages (WS) for level II (all taxa and skeletal elements considered). Null hypothesis: $p>0.05=$ no association, degrees of freedom $=1$. Associated weathering stages in bold.

\begin{tabular}{lcccc}
\hline \hline & WS1 & WS2 & WS3 & WS4 \\
\hline WS2 & $\chi^{2}=\mathbf{1 5 . 3 5 3}$ & & & \\
& $p<\mathbf{0 . 0 0 0 1}$ & & & \\
WS3 & $\chi^{2}=1.208$ & $\chi^{2}=\mathbf{8 . 3 1 0}$ & & \\
& $p=0.2718$ & $p=\mathbf{0 . 0 0 3 9}$ & & \\
WS4 & $\chi^{2}=0.0150$ & $\chi^{2}=1.843$ & $\chi^{2}=\mathbf{9 . 4 5 1}$ & \\
& $p=0.9020$ & $p=0.1745$ & $p=\mathbf{0 . 0 0 2 1}$ & \\
WS5 & $\chi^{2}=1.343$ & $\chi^{2}=1.535$ & $\chi^{2}=0.090$ & $\chi^{2}=\mathbf{4 . 4 6 8}$ \\
& $p=0.2466$ & $p=0.2153$ & $p=0.7642$ & $p=\mathbf{0 . 0 3 4 5}$ \\
\hline \hline
\end{tabular}

parts considered). Weathering is globally homogenous through the different body parts (all taxa considered) except when trunk elements (vertebrae and ribs) are compared with skull and extremities elements (Table 6). Anatomical differences and the high number of ribs and vertebrae in the faunal assemblage could explain why

TABLE 5. Weathering-stage profiles for the different skeletal parts of walrus, seals, and caribou found in level II.

\begin{tabular}{|c|c|c|c|c|c|c|c|c|c|c|}
\hline \multirow[b]{2}{*}{ Skeletal parts ${ }^{1}$} & & \multicolumn{2}{|c|}{ WS1 } & \multicolumn{2}{|c|}{ WS2 } & \multicolumn{2}{|c|}{ WS3 } & \multicolumn{2}{|c|}{$\mathrm{WS} 4+5$} & \multirow[b]{2}{*}{ Total } \\
\hline & & $\mathrm{N}$ & $\%$ & $\mathrm{~N}$ & $\%$ & $\mathrm{~N}$ & $\%$ & $\mathrm{~N}$ & $\%$ & \\
\hline \multicolumn{11}{|l|}{ Walrus } \\
\hline & A & 20 & 60.6 & 8 & 24.2 & 5 & 15.2 & 0 & 0.0 & 33 \\
\hline & B & 21 & 35.0 & 21 & 35.0 & 15 & 25.0 & 3 & 5.0 & 60 \\
\hline & $\mathrm{C} 1$ & 4 & 36.4 & 6 & 54.6 & 1 & 9.0 & 0 & 0.0 & 11 \\
\hline & $\mathrm{C} 2$ & 3 & 18.7 & 9 & 56.3 & 4 & 25.0 & 0 & 0.0 & 16 \\
\hline & D & 17 & 54.8 & 13 & 41.9 & 1 & 3.3 & 0 & 0.0 & 31 \\
\hline \multicolumn{11}{|l|}{ Seals } \\
\hline & A & 63 & 84.0 & 11 & 14.7 & 1 & 1.3 & 0 & 0.0 & 75 \\
\hline & B & 200 & 53.5 & 107 & 28.6 & 42 & 11.2 & 25 & 6.7 & 374 \\
\hline & $\mathrm{C} 1$ & 57 & 66.3 & 25 & 29.1 & 4 & 4.6 & 0 & 0.0 & 86 \\
\hline & $\mathrm{C} 2$ & 29 & 47.5 & 27 & 44.3 & 4 & 6.6 & 1 & 1.6 & 61 \\
\hline & $\mathrm{D}$ & 307 & 74.3 & 95 & 23.0 & 10 & 2.4 & 1 & 0.3 & 413 \\
\hline \multicolumn{11}{|l|}{ Caribou } \\
\hline & A & 12 & 52.2 & 11 & 47.8 & 0 & 0.0 & 0 & 0.0 & 23 \\
\hline & B & 2 & 40.0 & 3 & 60.0 & 0 & 0.0 & 0 & 0.0 & 5 \\
\hline & $\mathrm{C} 1$ & 6 & 85.7 & 1 & 14.3 & 0 & 0.0 & 0 & 0.0 & 7 \\
\hline & $\mathrm{C} 2$ & 9 & 37.5 & 10 & 41.7 & 2 & 8.3 & 3 & 12.5 & 24 \\
\hline & $\mathrm{D}$ & 33 & 54.1 & 12 & 19.7 & 11 & 18.0 & 5 & 8.2 & 61 \\
\hline
\end{tabular}

${ }^{1}$ Definition of the skeletal (butchery) parts: A = skull (cranium and mandible, ivory fragments are excluded); B = trunk (vertebrae and ribs); $\mathrm{C} 1$ = forelimb (scapula, humerus, radius, ulna); $\mathrm{C} 2=$ hindlimb (pelvis, femur, tibia, fibula); $\mathrm{D}=$ extremities (carpals, tarsals, metapodials, phalanges). 
TABLE 6. Kolmogorov-Smirnov Z with D statistics between all possible pairs of body parts (all taxa considered) for the three weathering categories (WS1+2; WS3; WS4+5) of level II.

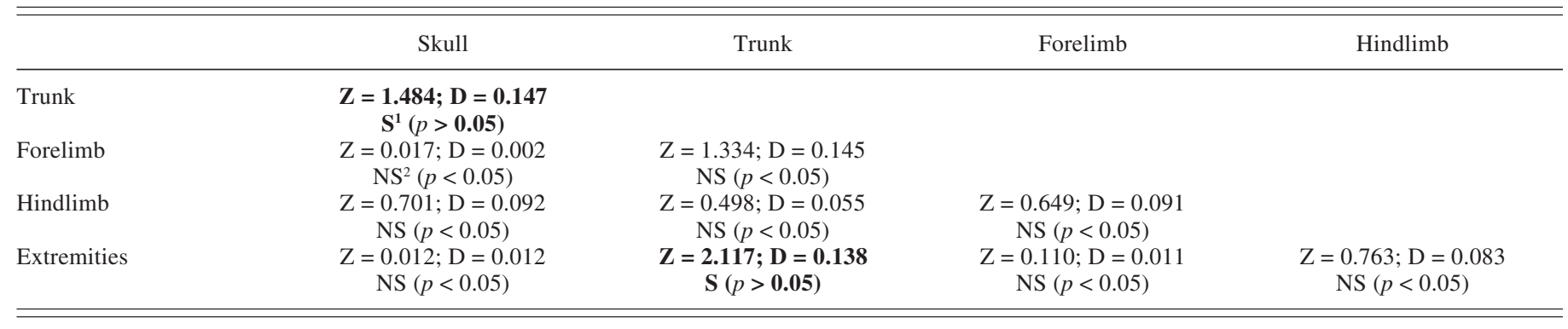

${ }^{1} \mathrm{~S}=$ significant difference between pairs of body parts.

${ }^{2} \mathrm{NS}=$ no significant difference between pairs of body parts.

trunk elements appear more weathered (Table 5). During the weathering processes, cracks affect all types of bones for all taxa and cracks affecting long bones are mainly longitudinal. Cracks are generally irregular with, mainly in the case of long bones, an absence of associated perpendicular cracking.

Beluga remains, represented by fragments of mandible and teeth $(29.4 \%)$, and ribs and vertebrae $(70.6 \%)$, are generally well preserved (WS1+2). Walrus is represented by trunk elements $(39.7 \%)$, cranial specimens $(21.9 \%)$, foot elements $(20.5 \%)$, hindlimb elements $(10.6 \%)$ and forelimb elements $(7.3 \%)$. Only one axis and two thoracic vertebrae belong to WS4. This suggests that walrus remains were minimally affected by weathering. Seal remains are also well preserved and are represented by extremities $(40.9 \%)$, trunk elements $(37.1 \%)$, forelimb elements $(8.5 \%)$, skull elements $(7.4 \%)$, and hindlimb elements (6\%). In the case of walrus and seals, the most deteriorated bones (WS4+5) include trunk elements (vertebrae and ribs, although in low percentages), which comprise spongy bone. Most of these bones were located in the area of squares $\mathrm{W}, \mathrm{X}$, and $\mathrm{Y}$, though this characteristic may be correlated to the high number of these remains in the assemblage rather than to a specific weathering stage. In this area bone preservation is generally poor, and burial is associated with thin overlying sediments (Figs. 5A and 6). Caribou is represented by extremities $(50.8 \%)$, skull elements $(19.2 \%)$, hindlimb elements $(20 \%)$, forelimb elements $(5.8 \%)$ and trunk elements $(4.2 \%)$. The bones that reflect the highest alteration (WS4+5) were mainly located in squares W204 and X202-204 (these represent a connected foot-metapodial and phalanges) and in square AG199, which contained a connected tarsal with calcaneus, navicular, and distal tibia. Other areas in the grid contained well-preserved caribou bones.

\section{Spatial Autocorrelation}

Spatial autocorrelation statistics using global Moran's I for the seven-order lag show the same tendencies for the three combined WS\% categories, all taxa and skeletal elements considered (Table 7). Because the number of squares and pairs decreased as the order lag increased, the area of squares $\mathrm{W}, \mathrm{X}$, and $\mathrm{Y}$ was not taken into account from the 3rd order lag. For all WS\% categories, there is a clear decrease of the Moran's I when order lag increases, with a tendency toward a negative GSA (Fig. 3). According to the normality assumption, the negative GSA is significant for WS $1+2 \%$ (from 4 th order lag) and WS3\% (from 5 th order lag), which means that nearby squares with higher order lags have dissimilar values of WS\% (dissimilar values are clustered in space). For WS $4+5 \%$, there is no significant GSA from the 3rd order lag, which means that there is no particular systematic structure on how the pattern is formed (random pattern). For all WS\% categories, the first two order lags are characterized by significant and positive GSA, which means that adjacent squares have similar values (similar values are clustered in space). The observed Moran's I is generally similar or close to the expected Moran's I for the 3rd (three categories of WS\%) and 4th order lag (WS3\% and WS4+5\%) with no significant GSA.

Unlike global Moran's I, LI measures the similarity between each square value and the values within its neighborhood. The LISA cluster and significance maps depict the locations of the 21 significant LI and the presence of significant spatial clusters (positive local spatial autocorrelation) and one spatial outlier (negative local spatial autocorrelation) for the WS $1+2 \%$ category (Figs. 5A and 5B). Hot spots of good bone preservation are indicated by significant spatial locations where high values of WS $1+2 \%$ are surrounded by high values. In contrast, cold spots of good bone preservation are indicated by significant spatial locations where low values of WS $1+2 \%$ are surrounded by low values. The spatial clusters shown on the LISA cluster map refer to only the core of the clusters. The spatial extent of the clusters is larger than suggested by their cores alone. This can be seen when comparing the LISA cluster map (Fig. 5A) to the density map for squares with high WS1+2\% (Figs. 3).

On the Moran scatterplot (Fig. 5C), the overall pattern of spatial association is positive, as indicated by the slope of the regression line (standardized Moran's I = 0.490). The upper right quadrant (32 squares, 55\%) and lower left 


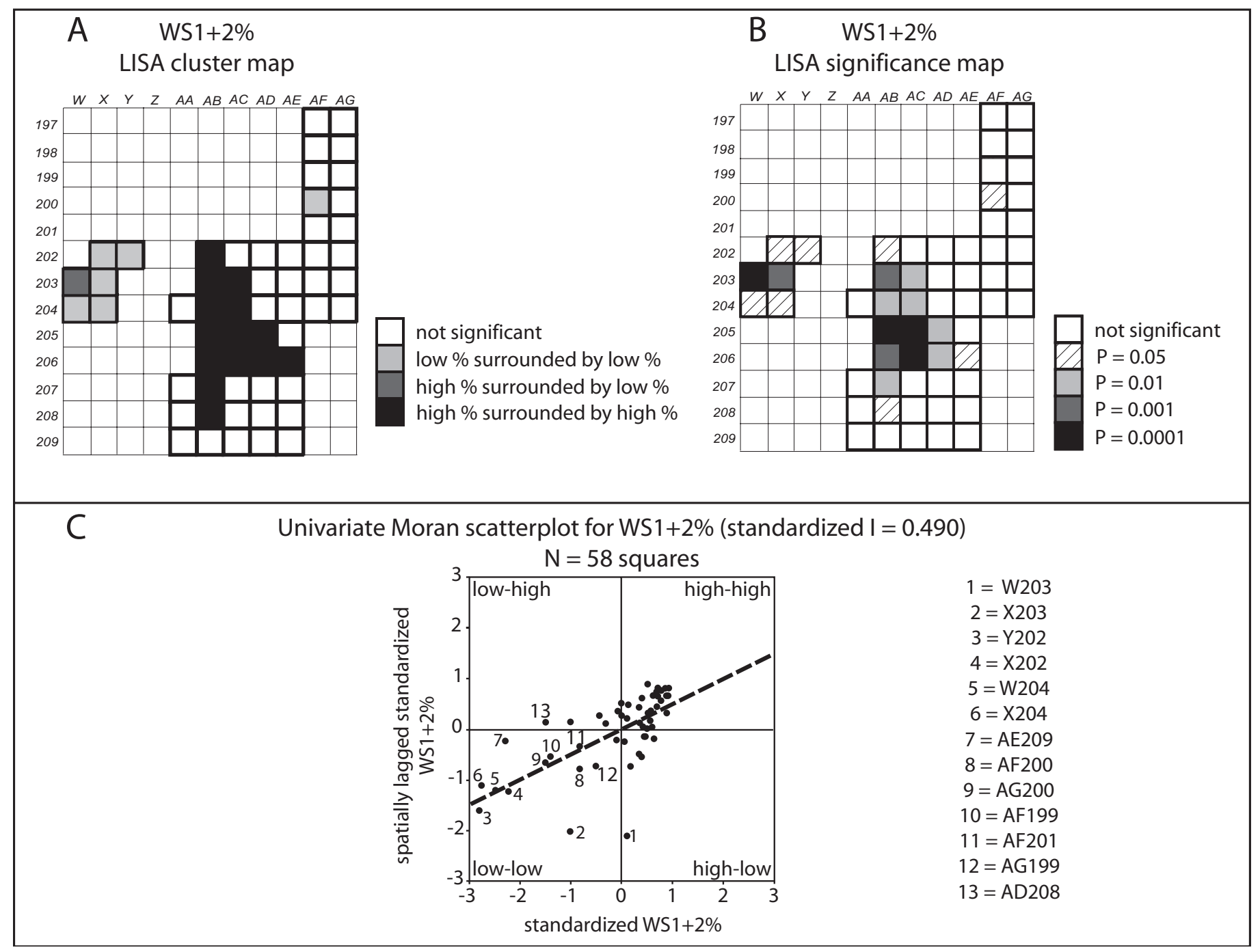

FIG. 5. (A) LISA cluster map, (B) associated significance map, and (C) univariate Moran's scatterplot for WS1+2\% of level II.

quadrant (12 squares, 21\%) indicate spatial clustering of similar values. The high-high quadrant corresponds to squares where bone preservation is good (high WS1+2\%) and includes 14 significant squares reported on the LISA cluster map (Fig. 5A). The low-low quadrant corresponds to squares where bone preservation is generally low (low or medium WS1+2\%, high WS3\% or WS4+5\%). It includes six significant squares with the W-X-Y area (except W203) and square AF200 reported on the LISA cluster map. Other non-significant squares comprise squares such as AE209 (high WS4+5\%), AG200 (high WS3\%), AF199 (high WS4+5\%), or AG199 and AF201 (relative medium WS $1+2 \%)$. The upper left quadrant (6 squares, 10\%) and lower right quadrant (8 squares, 14\%) indicate spatial association of dissimilar values (spatial outliers). In the high-low quadrant, square W203 is the only significant outlier, according to high WS1+2\%; it is also visible on the LISA cluster map. In the low-high quadrant, outliers, e.g., square AD208, showing low WS1+2\% and high WS3\%, are not significant.

\section{Bone Depth, Root Etching and Mineralization}

There is a close relationship between the mean depth of level II and the bone density per square for the three WS categories (Figs. 3 and 6A). An obvious relation linking WS1+2\% and bone depth is clearly outlined by both a statistically significant polynomial and a linear regression $(p<0.01)$, as shown by the F-test (Fig. 6B). The secondorder polynomial regression indicates that burial depth explains $56.65 \%$ of the variability in $\mathrm{WS} 1+2 \%$. For the linear regression, the model explains $52.73 \%$ of the variation in WS $1+2 \%$ and indicates a moderately strong relationship between the variables $(r=0.726)$. It is also interesting to note the close relationship between the mean depth of level II per square and the LISA cluster map (Figs. 5A and 6A). Significant hot spots of good bone preservation are closely related to deeper buried bones. In contrast, significant cold spots of good bone preservation are related to less deeply buried bones.

Variations in organic content of archaeological level II probably account for the fact that some bones (such as 


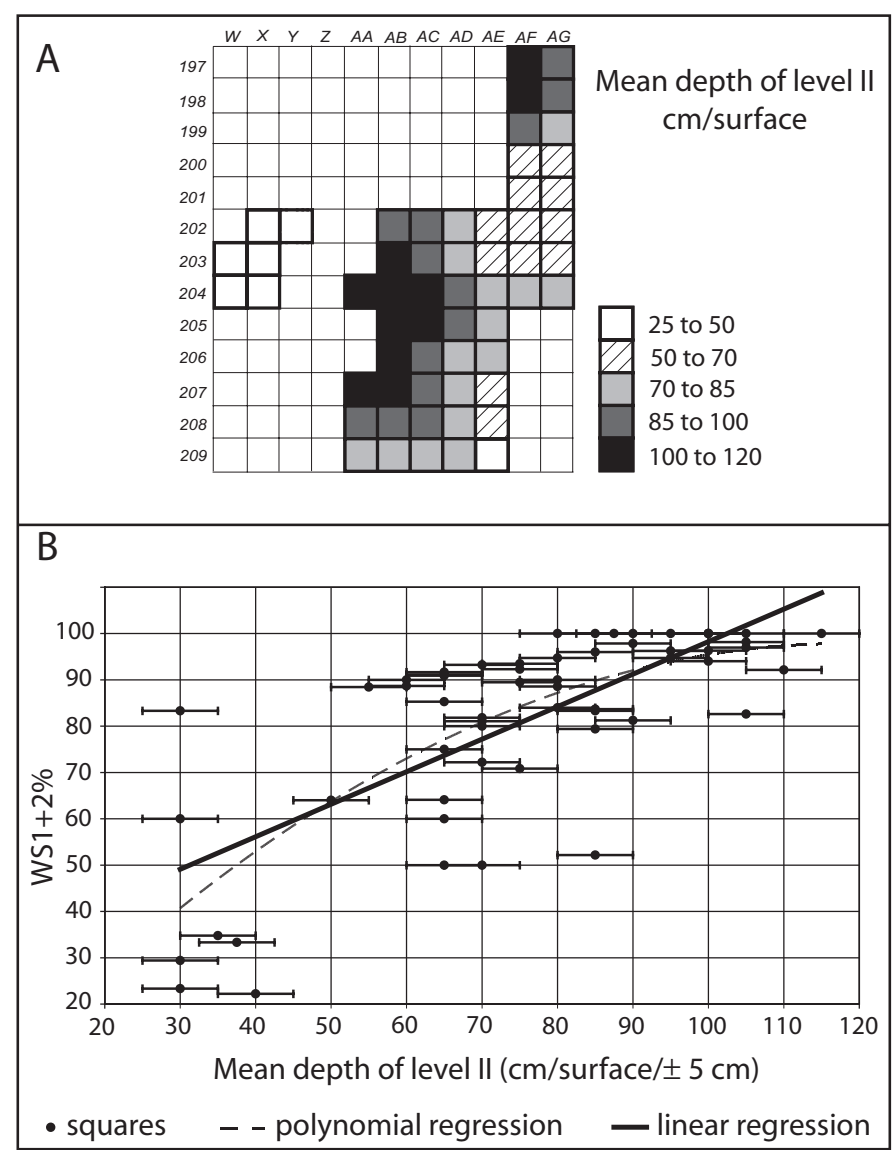

FIG. 6. (A) Mean depth of level II per square and (B) regression of WS1+2\% versus mean depth of level II ( $\pm 5 \mathrm{~cm}$ error). The excavated square W202 was not used because it lacked identified bone remains. Polynomial regression: $\mathrm{y}=-4.89045+1.74112 \mathrm{x}-0.00737709 \mathrm{x}^{2} ; \mathrm{R}^{2}=56.65, p$-value in ANOVA table $<0.01$; Linear regression: $\mathrm{y}=28.0233+0.702391 \mathrm{x} ; \mathrm{R}=0.726, \mathrm{R}^{2}=52.73$, $p$-value in ANOVA table $<0.01$.

metapodials, phalanges, and ribs) have a non-uniform weathering pattern throughout the entire cortical surface, either between the epiphysis and the diaphysis or between the two sides of the bones $(\mathrm{N}=83,5.2 \%$ for the level II assemblage). This differential weathering is likely related to the influence of the different microenvironments surrounding bones. Bone sides that are better preserved were probably in direct contact with sandier and less organic sediments. Conversely, bone sides that are less well preserved were probably preferentially exposed to edaphic conditions in more organic sediments. This differential and non-uniform weathering could then suggest minimal postburial movements (Todd and Frison, 1986).

Root etching is present on 309 remains (19.5\%) from level II and on 58 remains (94\%) from level III. It affects all species, skeletal elements and WS, except for the WS $4+5$ category because of the lack of cortical surface. Root etching for level II is non-randomly distributed $\left(\chi^{2}=\right.$ 443.001; $\mathrm{df}=58: p<0.001)$ but affected almost all squares $(88 \%)$ to varying degrees. There is generally a low incidence of root etching in level II, indicating that while the bones spent some time in the active root zone, burial was sufficiently rapid to remove them from the active root zone. This is probably true for the majority of squares, except where burial was less rapid or associated with thinner overlying sediments, or both. Indeed, observations show that the area of squares $\mathrm{W}, \mathrm{X}$, and $\mathrm{Y}$ is particularly affected by root etching and by the penetration of fresh roots inside the bones, indicating the influence of a (sub)present active root zone in this area. The bones of level III that seem to be more affected by root etching probably spent more time in the active root zone before burial.

Some denser and partially mineralized bones were also observed, often with a rugged or rough irregular surface: 41 were found in level II (2.6\%) and 27 in level III (44\%), which seems to have been more affected. The rugged bones of level II were not randomly distributed $\left(\chi^{2}=\right.$ $161.719 ; \mathrm{df}=58: p<0.001)$. Mineralization affected only 17 squares (30\%) without special relation to the depth of the bones. However, mineralization was not observed in squares with burial depth of less than $50 \mathrm{~cm}$. Partially mineralized bones are all well preserved (WS1+2), with all species and skeletal elements represented. The fact that mineralization is incomplete may reflect the relatively young age of the bones (Littleton, 2000). The relatively lower degree of bone mineralization of level II as compared to bones of level III could be related to their more recent burial.

\section{DISCUSSION: FACTORS EXPLAINING BONE PRESERVATION AT TAYARA}

In experiments carried out at high altitudes in the French Alps, Texier et al. (1998) emphasized the importance of the rapidity of damage on faunal remains left in a periglacial environment. According to Sutcliffe (1990), several factors appear to be important in controlling the rate of decay of mammalian remains in the Canadian High Arctic: 1) the position of remains and their relation to permafrost (whether they are buried or on the ground surface), 2) the amount of moisture, 3) the $\mathrm{pH}$ of the surrounding deposits or substrate, 4 ) the number of months of annual snow cover, and 5) the degree of exposure to temperature changes and other atmospheric processes. The excellent preservation of the bone assemblage at Tayara indicates that deterioration was not a major factor. WS are not associated with specific skeletal parts even if trunk elements of walrus and seals or hindlimbs and extremities of caribou seem slightly more weathered. Analysis reveals that differential bone weathering (all taxa and skeletal elements considered) is partly influenced by bone location. Squares with more highly weathered bones are those where the overlying sediments are thinner. In these squares, preburial or subsurface weathering, or both, was likely more predominant. Where overlying sediments are thicker (i.e., water-borne deposits and soliflucted sediments), it is likely that exposure to temperature changes, thermal stresses, desiccation, photochemical and 
TABLE 7. Spatial autocorrelation statistics of level II for the three categories of weathering stage percentage per square (WS\%) using univariate global Moran's I for the seven-order lag (all taxa and skeletal elements considered). The excavated square W202 was excluded for spatial autocorrelation statistics because it lacked identified bone remains.

\begin{tabular}{|c|c|c|c|c|c|c|c|c|c|c|c|}
\hline & \multirow[b]{3}{*}{ Order } & \multirow[b]{3}{*}{$\mathrm{N}$ squares } & \multirow[b]{3}{*}{$\mathrm{N}$ pairs } & \multirow{3}{*}{$\begin{array}{l}\text { Observed } \\
\text { Moran's I }\end{array}$} & \multirow{3}{*}{$\begin{array}{l}\text { Expected } \\
\text { Moran's I }\end{array}$} & \multicolumn{6}{|c|}{ One tailed-significance tests } \\
\hline & & & & & & \multicolumn{3}{|c|}{ Normality assumption } & \multicolumn{3}{|c|}{ Randomization assumption } \\
\hline & & & & & & Variance & Deviate & Probability & Variance & Deviate & Probability \\
\hline \multicolumn{12}{|l|}{ WS $1+2 \%$ : } \\
\hline & 1 & 58 & 324 & 0.378 & -0.018 & 0.006 & 5.220 & 0.000 & 0.006 & 5.277 & 0.000 \\
\hline & 2 & 57 & 430 & 0.274 & -0.018 & 0.004 & 4.581 & 0.000 & 0.004 & 4.634 & 0.000 \\
\hline & 3 & 52 & 438 & -0.020 & -0.020 & 0.004 & -0.004 & 0.498 & 0.004 & -0.004 & 0.498 \\
\hline & 4 & 52 & 398 & -0.141 & -0.020 & 0.005 & -1.804 & 0.036 & 0.004 & -1.838 & 0.033 \\
\hline & 5 & 52 & 344 & -0.220 & -0.020 & 0.005 & -2.774 & 0.003 & 0.005 & -2.826 & 0.002 \\
\hline & 6 & 52 & 264 & -0.303 & -0.020 & 0.007 & -3.416 & 0.000 & 0.007 & -3.481 & 0.000 \\
\hline & 7 & 48 & 176 & -0.292 & -0.021 & 0.010 & -2.647 & 0.004 & 0.010 & -2.697 & 0.004 \\
\hline \multicolumn{4}{|l|}{ WS3\%: } & 0.171 & -0.018 & 0.006 & 2.485 & 0.006 & 0.005 & 2.552 & 0.005 \\
\hline & 2 & 57 & 430 & 0.187 & -0.018 & 0.004 & 3.215 & 0.001 & 0.004 & 3.298 & 0.000 \\
\hline & 3 & 52 & 438 & -0.044 & -0.020 & 0.004 & -0.384 & 0.351 & 0.004 & -0.401 & 0.344 \\
\hline & 4 & 52 & 398 & -0.039 & -0.020 & 0.005 & -0.296 & 0.384 & 0.004 & -0.310 & 0.378 \\
\hline & 5 & 52 & 344 & -0.152 & -0.020 & 0.005 & -1.825 & 0.034 & 0.005 & -1.913 & 0.028 \\
\hline & 6 & 52 & 264 & -0.167 & -0.020 & 0.007 & -1.779 & 0.038 & 0.006 & -1.866 & 0.031 \\
\hline & 7 & 48 & 176 & -0.215 & -0.021 & 0.010 & -1.894 & 0.029 & 0.009 & -1.990 & 0.023 \\
\hline \multicolumn{12}{|l|}{ WS4+5\%: } \\
\hline & 1 & 58 & 324 & 0.152 & -0.018 & 0.006 & 2.234 & 0.013 & 0.005 & 2.381 & 0.009 \\
\hline & 2 & 57 & 430 & 0.145 & -0.018 & 0.004 & 2.559 & 0.005 & 0.004 & 2.723 & 0.003 \\
\hline & 3 & 52 & 438 & -0.021 & -0.020 & 0.004 & -0.022 & 0.491 & 0.003 & -0.026 & 0.490 \\
\hline & 4 & 52 & 398 & -0.052 & -0.020 & 0.005 & -0.485 & 0.314 & 0.003 & -0.572 & 0.284 \\
\hline & 5 & 52 & 344 & -0.092 & -0.020 & 0.005 & -1.005 & 0.157 & 0.004 & -1.186 & 0.118 \\
\hline & 6 & 52 & 264 & -0.141 & -0.020 & 0.007 & -1.467 & 0.071 & 0.005 & -1.736 & 0.041 \\
\hline & 7 & 48 & 176 & -0.160 & -0.021 & 0.010 & -1.361 & 0.087 & 0.007 & -1.626 & 0.052 \\
\hline
\end{tabular}

photomechanical processes, and other atmospheric processes was limited. For the majority of the analyzed squares, permanent sedimentation likely occurred very rapidly after human occupation, and bones were therefore exposed for only a short time. This could explain why a significant WS4-5\% per square is infrequent, except for squares where burial is associated with thinner overlying sediments.

Nevertheless, because some highly weathered bones were located in squares where burial is associated with thicker overlying sediments, differential bone depth probably does not explain all bone weathering variability within the site. Guadelli and Ozouf (1994) showed that the impact of frost on bones is characterized by great variability, with some bones reacting quickly and others more slowly. The present analysis indicates that weathering did not affect any particular taxon, and all taxa showed a similar weathering profile. In the same way, no skeletal part was preferentially weathered or characterized by a specific WS. It is likely that differential bone size, shape, porosity or density might have enhanced differential weathering (Lyman, 1994), but this hypothesis was not investigated in depth (for each bone element) in the present study. Moreover, microenvironments, burial history (i.e., including temporary burial, reemergence, or both), bone depth, and bone specificities (such as size, shape, age, density, ante-mortem health status of the individual) are too variable to confirm the assumption that weathering and time since death are correlated (Behrensmeyer, 1978; Potts, 1986). Indeed, there are difficulties in using the degree of weathering as a clue to the age of a bone (Lyman and Fox, 1989; Littleton, 2000). Differential weathering is probably not related to the age of the remains. Therefore, it appears difficult to correlate more weathered bones with older occupation levels.

The active periglacial environment (i.e., low temperatures, short growth season) probably inhibited bone deterioration due to limited chemical or microbial weathering before or at the time of burial. Bone integration in the active layer likely inhibited postburial chemical, microbial and mechanical weathering, insofar as bones and sediments remained frozen during the major part of the year. Collins et al. (2002) found that long-term bone survival in optimal burial environments depends upon time and temperature. Indeed, the microbial (fungi, bacteria, protozoa) and chemical degradation of bones is strongly influenced by temperature and other parameters of the burial environment, including oxygen and water availability (White and Hannus, 1983; Von Endt and Ortner, 1984). Abnormally low temperatures inhibit microbiological attack, and the specific conditions in which microbial and chemical bone deterioration is retarded are associated with pickling, drying, tanning and freezing (Collins et al., 1998, 2002). At Tayara, much bone deterioration is probably related to processes of mechanical origin that occurred before or after burial, with additional root action on bones in the root zone. It is likely that root etching occurred in the preburial period during organic horizon formation. During the period of organic accumulation and low stream sedi- 
mentation, vegetation growth may have protected some bones from further perturbation or damage. The generally well-preserved condition of the bones and the absence of dissolution features indicate limited weathering induced by the acidity of the surrounding soil sediments.

Abiotic processes such as freezing-thawing and wetting-drying may have promoted bone cracking before or around the time of burial (Miller, 1975; Murphy et al., 1981; Guadelli and Ozouf, 1994). Miller (1975) showed that freeze-thaw and wet-dry cycles produce longitudinal and transversal cracks similar to those found in our early WS (especially longitudinal cracks). Miller (1975) observed no differences in the kind of fractures produced on different bones, as we also observed for the Tayara bone assemblage. Murphy et al. (1981) indicated that bones subjected to wet-dry cycles display cracking, cortical lifting, or distortion. Johnson (1985) stressed the role of desiccation in the weathering process. Severe desiccation causes exfoliation while a bone is exposed on the surface, resulting in the delamination of the cortical surface. Johnson (1985) also stated that freezing is a desiccation process that removes moisture from bone and therefore alters its physical properties and biomechanical response to force. Finally, Guadelli and Ozouf (1994) showed that the effect of frost on faunal remains is, to some degree, independent of the degree of humidity. They also reported that beyond $900-1000$ freeze-thaw cycles, fragmentation becomes so intense that bone fragments can no longer be identified.

At Tayara, for the majority of the analyzed bones, a rapid and permanent burial is suggested by the absence of bleached bones with a soft, chalky superficial layer, which likely reflects low sun exposure (with limited summer bone desiccation) and low wind erosion (sandblasting, abrasion) before burial. Bones with advanced exfoliation, as in WS3, were likely affected by weathering that caused delamination along cracks either before or at the time of burial. The deepening and enlarging of cracks, in addition to cortical disappearance and induced appearance of spongiosa (WS4+5), may also be viewed as the effects of frost, wetting-drying, or both before protective burial. The unidentified bones such as splinters and smaller remains may be the result of freezing-thawing or wetting-drying, even if trampling or some human activities may also have contributed to their formation.

As revealed by weathering analysis, the majority of the Tayara bone assemblage is well preserved. This indicates that freeze-thaw and wet-dry cycles were too inefficient to promote extensive bone weathering and frost-shattering either before or after burial. The presence of snow cover during the major part of the year may have been protective, as well as the long duration of winter, and the limited frequency of freeze-thaw cycles. The fact that all analyzed bones were buried in the active layer means that freezethaw cycles did not play a significant role in bone weathering after burial. In the same way, the role of postburial wetting-drying (and severe desiccation) in bone weathering was likely limited for the majority of analyzed bones.
Their limited role is suggested by the low evaporation rate, the existence of continuous permafrost (limiting downward water percolation), and the shortness of the summer associated with the melting of snow cover and ground ice, all of which promote soil dampness during the major part of the short melt period. However, the soil dampness caused by the summer thaw may have favored the decay of remnant soft tissues after animal butchering and before complete burial (Sutcliffe, 1990).

\section{CONCLUSION}

Weathering analysis can provide important information on site taphonomy. For the Tayara site, the Palaeoeskimo bone assemblage is relatively well preserved, even if some differences in the spatial patterning of weathering were observed within the site. Statistical analyses revealed no significant differences between taxa and skeletal parts. Bone preservation by square appears to be partly correlated with burial depth. Significantly weathered bones in squares where burial is associated with thinner overlying sediments may be related to longer preburial weathering, slower burial, more efficient subsurface weathering with respect to abiotic processes, or a combination. In contrast, the better preservation of bones, which tends to occur in squares where burial is associated with thicker overlying sediments, is likely due to more rapid burial and a lower degree of exposure to temperature changes and other atmospheric processes. Once buried, the integration of bones in the active layer probably inhibited weathering. Since some significantly weathered bones are located in squares where overlying sediments are thicker, differential bone depth probably does not explain all weathering variability over the site.

Further research will have to be undertaken in order to elucidate the influence of bone specificities (age, size, shape, porosity or density) on weathering, as well as the differences or similarities between level II and level III. Intersite comparisons will be also necessary to control for variables that influence bone weathering in periglacial environments of Arctic regions. Future spatial analyses (i.e, spatial autocorrelation and multivariate statistics) based on more precise faunal determinations (seal species, age and sex of the animals), and also lithic and organic industries data, should help the interpretation of archaeological spatial patterning. This will aid determination of the season and duration of site occupations and the ways in which Palaeoeskimos organized their living space, their sharing of food, and their food habits. In conjunction with taphonomic analyses (i.e., bone orientation, lithic artifact sorting, refitting artifacts), intra-site spatial analyses should allow us to clarify the activity areas, such as the preference areas of cutting, meat storage, tool and harpoon preparation, and butchering and cooking areas. 


\section{ACKNOWLEDGEMENTS}

This study is a contribution of the From Tuniit to Inuit project of the CURA program supported by the SSHRC. Dominique Todisco thanks Najat Bhiry from the Centre d'études nordiques of Laval University for funding provided by NSERC. Participation of Hervé Monchot in this project was facilitated by a grant from the QFRNT. Helpful discussions with P.M. Desrosiers and D. Gendron from the Avataq Cultural Institute were much appreciated. We also acknowledge M. Allard, P. Bertran, N. Bhiry, C.M. Darwent, L.K. Horwitz, and three anonymous reviewers who commented on an early draft of this paper. Thanks to J. Piérard, A. Bisaillon, A. Burke, and M.H. Vandersmissen for help in our work, and to the young Inuit of Salluit who took part in the excavations of the Tayara site.

\section{REFERENCES}

ALLARD, M., and SÉGUIN, M.K. 1987. Le pergélisol au Québec nordique: Bilan et perspective. Géographie Physique et Quaternaire 41:141-152.

ANDREWS, P., and ARMOUR-CHELU, M. 1997. Taphonomic observations on a surface bone assemblage in a temperate environment. Bulletin de la Société Géologique de France 169:433-442.

ANDREWS, P., and COOK, J. 1985. Natural modifications to bones in a temperate setting. Man 20:675-691.

ANSELIN, L. 1995. Local indicators of spatial association - LISA. Geographical Analyses 27:93-115.

- 2003. GeoDa 0.9 User's Guide. Urbana-Champaign: Spatial Analyses Laboratory, University of Illinois.

AVATAQ CULTURAL INSTITUTE. 2004. Three years of research at the Tayara site (KbFk-7), Qikirtaq. Summer fieldwork 2003 and preliminary synthesis. CURA 2001-2003 from Tuniit to Inuit. Report presented to Government of Nunavut, Department of Cultural Heritage, Inuit Heritage Trust, Prince of Wales Northern Heritage Centre and Canadian Museum of Civilization, Hull, Quebec.

BEHRENSMEYER, A.K. 1978. Taphonomic and ecologic information from bone weathering. Paleobiology 4:150-162.

1990. Transport-hydrodynamics: Bones. In: Briggs, D.E.G., and Crowther, P.R., eds. Palaeobiology: A synthesis, Oxford: Blackwell Scientific Publications. 232-235.

BOUCHARD, F. 2005. Topoclimat et microclimats de la vallée de Salluit (Nunavik). Influence sur le régime thermique du pergélisol. MSc thesis, Department of Geography, Laval University, Quebec.

CLIFF, A.D., and ORD, J.K. 1973. Spatial autocorrelation. London: Pion.

COLlinS, M.J., WALTON, D., and KING, A. 1998. The geochemical fate of proteins. In: Stankiewitz, B.A., and van Bergen, P.F., eds. Nitrogen-containing macromolecules in the bio- and geosphere. ACS Symposium Series 707. New York: Oxford University Press. 74-87.

COLLINS, M.J., NIELSEN-MARSH, C., HILLER, J., SMITH, C., ROBERTS, J., MILlARD, A., WESS, T., CSAPO, J.,
PRIGODICH, R., and TURNER-WALKER, G. 2002. The survival of organic matter in bone: A review. Archaeometry 44:383-394.

DACEY, M.F. 1973. Statistical tests of spatial association in the locations of tool types. American Antiquity 38:320-328.

DARWENT, C.M. 1995. Late Dorset faunal remains from the Tasiarulik site, Little Cornwallis Island, Central High Arctic. MSc thesis, Department of Archaeology, Simon Fraser University, Burnaby, British Columbia.

DENYS, C., ANDREWS, P., DAUPHIN, Y., WILLIAMS, T., and FERNANDEZ-JALVO, Y. 1997. Towards a site classification: Comparison of stratigraphic, taphonomic and diagenetic patterns and processes. Bulletin de la Société Géologique de France 168:751-757.

DESROSIERS, P.M., and GENDRON, D. 2004. The Tayara site and the concept of Early Dorset. 69th Annual Meeting, Society for American Archaeology, 31 March - 4 April 2004, Montreal, Canada.

DESROSIERS, P.M., GENDRON, D., and RAHMANI, N. 2006. Harpoon head seriation and the Dorset phases: About the Tayara sliced and the other types. In: Arneborg, J., and Grønnow, B., eds. Studies in Archaeology and History, Vol. 10. Copenhagen: Publications from the National Museum. 131-143.

EFREMOV, I.A. 1940. Taphonomy: A new branch of paleontology. Pan-American Geologist 74:81-93.

GENDRON, D., DESROSIERS, P.M., and RAHMANI, N. 2003. New excavation at the Tayara site. 36th Annual Conference of the Canadian Archaeological Association, 7-10 May 2003, McMaster University, Hamilton, Ontario.

GERARDIN, V., and McKENNEY, D. 2001. Une classification climatique du Québec à partir de modèles de distribution spatiale de données climatiques mensuelles: Vers une définition des bioclimats du Québec. Contribution du Service de la Cartographie Ecologique, No. 60. Québec: Ministère de l'environnement, Direction du patrimoine écologique et du développement durable.

GOODCHILD, M.F. 1986. Spatial autocorrelation. CATMOG No. 47, Norwich: Geo Books.

GRAY, J.T., LAURIOL, B., BRUNEAU, D., and RICARD, J. 1993. Postglacial emergence of Ungava Peninsula, and its relationship to glacial history. Canadian Journal of Earth Sciences 30:1676-1696.

GUADELLI, J.L., and OZOUF, J.C. 1994. Etudes expérimentales de l'action du gel sur les restes fauniques: Premiers résultats. In: CEDARC, eds. Outillages peu élaboré en os et bois de cervidés IV, Taphonomie/Bone modification, Artefacts No. 9, Treignes, Belgique. 47-56.

HAGLUND, W.D. 1991. Applications of taphonomic models to forensic investigations. PhD thesis, Department of Anthropology, University of Washington, Seattle, Washington.

HILL, A. 1979. Disarticulation and scattering of mammal skeletons. Paleobiology 5:261-274.

JOHNSON, E. 1985. Current developments in bone technology. Advances in Archaeological Method and Theory 8:157-235.

KASPER, J.N., and ALLARD, M. 2001. Late Holocene climatic changes as detected by the growth and decay of ice wedges on the southern shore of Hudson Strait, northern Quebec, Canada. The Holocene 11:563-577. 
KLEIN, R.G., and CRUZ-URIBE, K. 1984. The analysis of animal bones from archaeological sites. Chicago: University of Chicago Press.

LEMOINE, G.M., and DARWENT, C. 1998. The walrus and the carpenter: Late Dorset ivory working in the High Arctic. Journal of Archaeological Science 25:73-83.

LITTLETON, J. 2000. Taphonomic effects of erosion on deliberately buried bodies. Journal of Archaeological Science 27:5-18.

LYMAN, R.L. 1984. Bone density and differential survivorship of fossil classes. Journal of Anthropological Archaeology 3: 259-299.

. 1992. Prehistoric seal and sea-lion butchering on the southern Northwest Coast. American Antiquity 57:246-261.

- 1994. Vertebrate taphonomy. Cambridge: Cambridge University Press.

LYMAN, R.L., and FOX, G.L. 1989. A critical evaluation of bone weathering as an indication of bone assemblage formation. Journal of Archaeological Science 16:293-317.

LYMAN, R.L., SAVELLE, J.M., and WHITRIDGE, P. 1992. Derivation and application of a meat utility index for phocid seals. Journal of Archaeological Science 19:531-555.

MILLER, G.J. 1975. A study of cuts, grooves and other marks on recent fossil bone: II Weathering cracks, fractures, splinters, and other similar natural phenomena. In: Swanson, E., eds. Lithic technology: Making and using stone tools. The Hague: Mouton. $211-226$.

MONCHOT, H., CHAZAN, M., and HORWITZ, L.K. In press. Testing the spatial association of lithic and faunal remains: A case study from the Lower Paleolithic site from Holon (Israel). In: Seetah, K., and Gravina, B., eds. Bones for tools, tools for bones: The interrelationship of lithic and bone raw materials. Cambridge: McDonald Institute of Archaeology, Cambridge University.

MURPHY, L., BARNETT, B.G., HOLLOWAY, R.G., and SHELDON, C.M. 1981. An experiment to determine the effects of wet/dry cycling on certain common cultural materials. In: Lenihan, D.J., Carrell, T.L., Fosberg, S., Murphy, L., Rayl, S.L., and Ware, J.A., eds. The final report of the National Reservoir Inundation Study. Technical Report 8-1-8-43. Sante Fe, New Mexico: USDI, National Park Service, Southwest Cultural Resources Center. Vol. 2.

NAGY, M.I. 1997. Palaeoeskimo cultural transition: A case study from Ivujivik, Eastern Arctic. PhD thesis, Department of
Anthropology, University of Alberta, Edmonton. Nunavik Archaeology Monograph Series, No.1. Inukjuak, Nunavik: Avataq Cultural Institute.

PIELOU, E.C. 1977. Mathematical ecology. New York: John Wiley.

POTTS, R. 1986. Temporal span of bone accumulations at Olduvai Gorge and implications for early hominid foraging behavior. Paleobiology 12:25-31.

SCHIFFER, M.B. 1983. Toward the identification of formation processes. American Antiquity 48:675-706.

SUTCLIFFE, A.J. 1990. Rates of decay of mammalian remains in the permafrost environment of the Canadian High Arctic. In: Harington, C.R., ed. Canada's missing dimension: Science and history in the Canadian Arctic Islands. Vol. 1. Ottawa: Canadian Museum of Nature. 161-186.

TAPPEN, M. 1994. Bone weathering in the tropical rain forest. Journal of Archaeological Science 21:667-673.

TAYLOR, W.E. 1968. The Arnapik and Tyara sites: An archaeological study of Dorset culture origins. Memoirs of the Society for American Archaeology 22. Salt Lake City: Society for American Archaeology.

TEXIER, J.P., BERTRAN, P., COUTARD, J.P., FRANCOU, B., GABERT, P., GUADELLI, J.L., OZOUF, J.C., PLISSON, H., RAYNAL, J.P., and VIVENT, D. 1998. TRANSIT, an experimental archaeological program in periglacial environment: Problem, methodology, first results. Geoarchaeology 13: $433-473$.

THERIAULT, M. 1998. MapStat version 1.2: Spatial statistics for MapInfo $^{\text {TM }}$. Centre de Recherche en Aménagement et Développement (CRAD), Canada. Copyright 1994, 1996, 1998.

TODD, L.C., and FRISON, G.C. 1986. Taphonomic study of the Colby site mammoth bones. In: Frison, G.C., and Todd, L.C., eds. The Colby Mammoth Site: Taphonomy and archaeology of a Clovis kill in northern Wyoming. Albuquerque: University of New Mexico Press. 27-90.

TODISCO, D., and BHIRY, N. In press. Palaeoeskimo site burial by solifluction: Periglacial geoarchaeology of the Tayara site (KbFk-7), Qikirtaq Island, Nunavik (Canada). Geoarchaeology.

VON ENDT, D., and ORTNER, D. 1984. Experimental effects of bone size and temperature on bone diagenesis. Journal of Archaeological Science 11:247-253.

WHITE, E.M., and HANNUS, L.A. 1983. Chemical weathering of bone in archaeological soils. American Antiquity 48:316-322. 